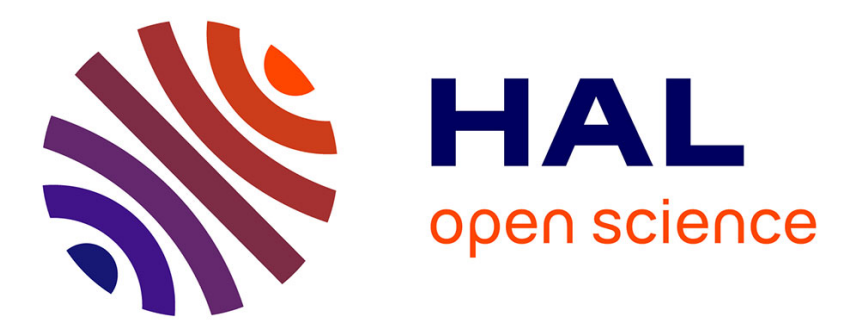

\title{
Synthesis and chemical reactivity of new zinc porphyrin diazoacetates catalyzed by ruthenium and iron porphyrins
}

Daniel Carrié, Hassan Srour, Paul Le Maux, Gérard Simonneaux

\section{- To cite this version:}

Daniel Carrié, Hassan Srour, Paul Le Maux, Gérard Simonneaux. Synthesis and chemical reactivity of new zinc porphyrin diazoacetates catalyzed by ruthenium and iron porphyrins. Tetrahedron Letters, 2016, 57 (10), pp. 1179-1182. 10.1016/j.tetlet.2016.02.010 . hal-01269738

HAL Id: hal-01269738

https://hal-univ-rennes1.archives-ouvertes.fr/hal-01269738

Submitted on 22 Apr 2016

HAL is a multi-disciplinary open access archive for the deposit and dissemination of scientific research documents, whether they are published or not. The documents may come from teaching and research institutions in France or abroad, or from public or private research centers.
L'archive ouverte pluridisciplinaire HAL, est destinée au dépôt et à la diffusion de documents scientifiques de niveau recherche, publiés ou non, émanant des établissements d'enseignement et de recherche français ou étrangers, des laboratoires publics ou privés. 


\section{Synthesis and chemical reactivity of new zinc porphyrin diazoacetates catalyzed by ruthenium and iron porphyrins}

\section{Daniel Carrie, Hassan Srour, Paul Le Maux and Gerard Simonneaux*}

Ingénierie Chimique et Molécules pour le Vivant, UMR 6226, Campus de Beaulieu, 35042 Rennes Cedex, France

e-mail address : gerard.simonneaux@univ-rennes1.fr

fax number: 33(0)2 23235637

\section{Abstract}

Zinc porphyrin diazoacetates were synthesized from the corresponding bromoacetates by treatment with N,N'-ditosylhydrazine in $\sim 70 \%$ yield. The transfer of carbenoids derived from the porphyrin diazo compounds catalyzed by metalloporphyrins ( $\mathrm{Ru}, \mathrm{Fe})$ undergoes dimerization, cyclopropanation, N-H and S-H insertion reactions, respectively.

\section{Graphical abstract}

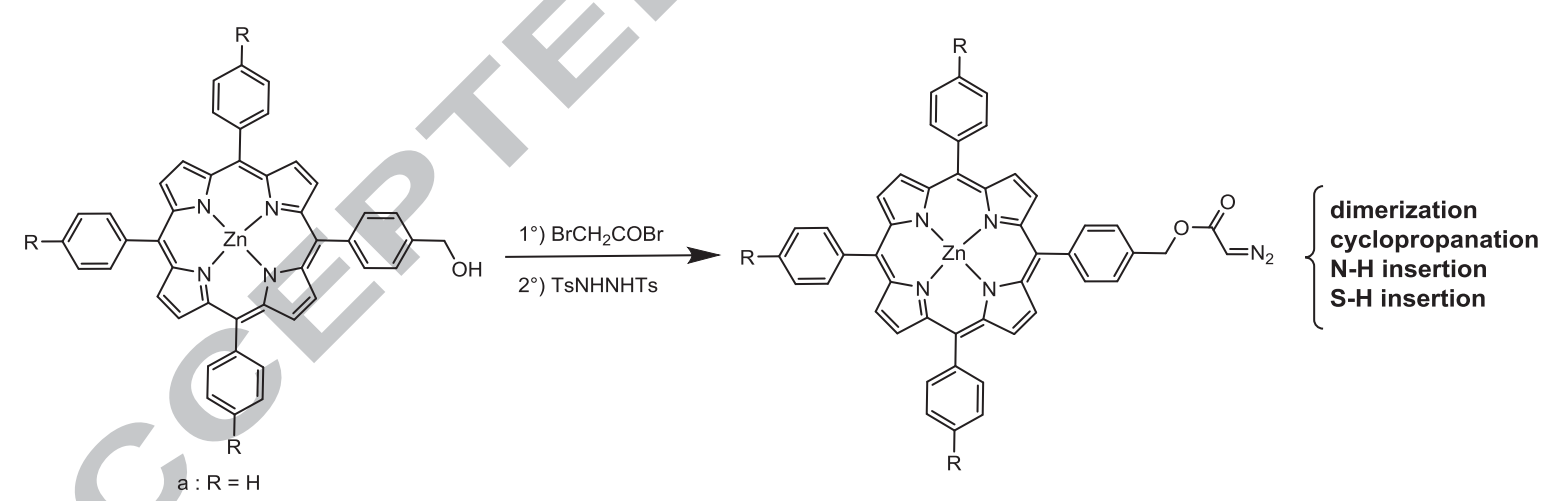

Keywords:

Meso-phenyl-diazo-porphyrin ester, ruthenium porphyrin, iron porphyrin, catalytic carbene transfer

The applications of diazocarbonyl compounds to organic synthesis still continue to attract the attention of many chemists. ${ }^{1}$ Various methodologies have been developed for 
preparing different types of diazocarbonyl compounds and there are now well-established procedures. $^{1,2}$ Important examples of these processes include the functionalization of porphyrin macrocycles using diazo compounds which has been recently reviewed. ${ }^{3}$ Thus porphyrin derivatives such as chlorins with a diazo function in the macrocycle core were first reported by Cavaleiro and coworkers in $1997 .{ }^{4}$ These chlorin diazoketones can be used as versatile intermediates for the synthesis of new compounds. ${ }^{5}$ In 2006, Zaleski's group reported an alternative strategy to obtain 2-diazo-3-oxochlorins. ${ }^{6}$ In all these cases, the diazo group is directly inserted in the core yielding chlorin derivatives and to our knowledge, there is no diazo group directly appended to the periphery of the porphyrin ring. We previously reported the use of metalloporphyrins for catalytic insertion of diazo compounds in $\mathrm{N}-\mathrm{H}$ bonds, ${ }^{7,8}$ including insulin protein. ${ }^{9}$ Asymmetric cyclopropanation was also developed using chiral iron and ruthenium porphyrins as catalysts. ${ }^{10,11}$ In this paper, we report the first synthesis of zinc porphyrin diazoacetates and some of their reactivity using metalloporphyrins as catalysts (Figure 1).

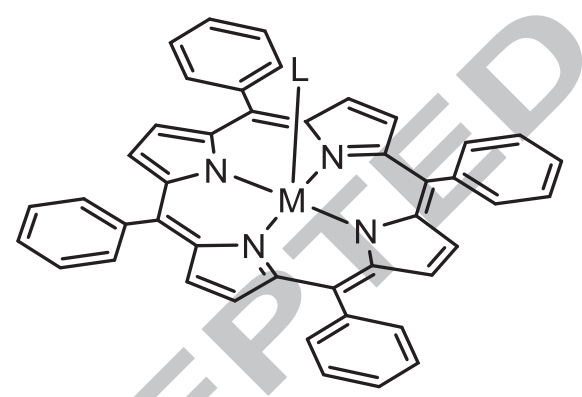

M-L RuCO: TPPRuCO

M-L Fe-Cl: TPPFeCl

Figure 1. Structure of the catalysts.

A convenient synthetic method for the preparation of a variety of diazoacetates from the corresponding bromoacetates by treatment with N,N'-ditosylhydrazine has been recently reported. ${ }^{12}$ Herein, we successfully used this recent method with hydroxymethyl-porphyrins that were prepared as previously reported by Tamiaki. ${ }^{13}$ After Zn metalation, reaction with bromoacetate and then with N,N'-ditosylhydrazine yielded the expected diazo derivatives. From 5-[4-(hydroxymethyl)phenyl]-10,15,20-triphenylporphyrin, the corresponding zinc diazoporphyrin ester 1a was prepared in 72\% yield (Scheme 1). Similar results were obtained with 5-[4-(hydroxymethyl)phenyl]-10,15,20-5-[4-(hydroxymethyl)phenyl]-10,15,20-tris(4methoxyphenyl)porphyrin giving $\mathbf{1 b}$ with 67\% yield. These diazo esters were first characterized by ${ }^{1} \mathrm{H}$ and ${ }^{13} \mathrm{C}$ NMR and mass spectrometry. A characteristic diazo proton at 
$\sim 5.0 \mathrm{ppm}$ as a broad peak was observed in the ${ }^{1} \mathrm{H}$ NMR spectrum. It should be noted that a preliminary zinc insertion is essential for the synthesis since free base porphyrins gave only traces of diazo derivatives. The general synthetic pathway is summarized in Scheme 1.<smiles>[R]c1ccc(C=O)cc1</smiles>
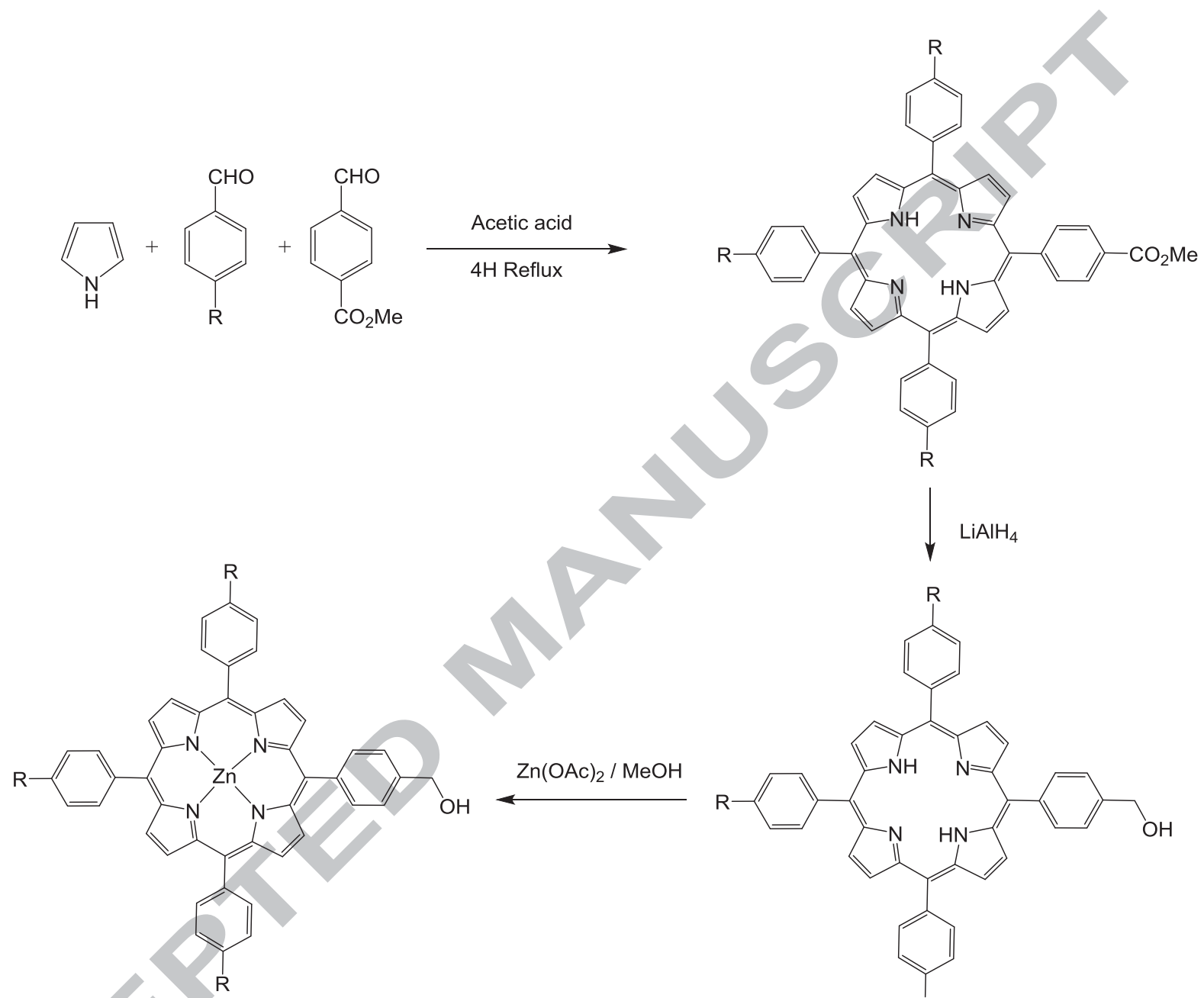

$\mathrm{Zn}(\mathrm{OAc})_{2} / \mathrm{MeOH}$


Scheme 1. General pathway for the synthesis of Zn diazoporphyrin ester derivatives. 
To demonstrate the presence of possible metallocarbene intermediate, first its decomposition to form olefinic products at room temperature in the presence of tetraphenylporphyrin ruthenium carbon monoxide (Figure 1) as catalyst was examined. Starting from 1a, this coupling reaction catalyzed by ruthenium porphyrin to form olefins, proceeds slowly, possibly through a metallocarbene intermediate, yielding the cis isomer $\mathbf{2}$ in overall 91\% yield (Scheme 2). In our hands, the trans isomer was not detected. ${ }^{14}$ However the reaction needs 24 hours to be completed. In comparison, a similar ruthenium(II) porphyrin species has been reported to catalyze rapidly the decomposition of ethyl diazoacetate to form diethyl maleate and diethyl fumarate with a large cis/trans ratio of $15 .{ }^{15}$ The stereochemical contraints that result from the steric interaction of the axial porphyrin carbene atoms with atoms of the porphyrinato core ${ }^{16}$ may explain the decrease of the rate. The generally accepted reaction pathway for transition metal catalyzed carbene dimerization of diazo derivatives involves initial attack of the diazo compound at the metal center to generate a metal carbene. ${ }^{17,18}$ Nucleophilic attack on the metal carbene by diazo compound, followed by dissociation of the olefin from the metal complex, completes the catalytic cycle. The origin of the cis selectivity during the coupling of $\alpha$-diazo compounds has been previously interpreted on the basis of steric and electronic effects. ${ }^{19-21}$

To evaluate the reactivity of diazo porphyrin ester, its catalytic decomposition was also examined in the presence of styrene in toluene at room temperature using tetraphenylporphyrin ruthenium carbon monoxide (Figure 1) as catalyst. The cyclopropane 3 was formed with 79\% yield and complete trans diastereoselectivity with a concomitant formation of the dimer (15\%), resulting from coupling of two carbene precursors. The formation of the trans isomer, which was confirmed by NOESY spectroscopy, is similar to that observed when ethyl diazoacetate is used as reactant. ${ }^{22}$

The insertion of electrophilic carbenes in the N-H bonds of protected $\alpha$-amino esters or amides is a powerful method for N-alkylating this class of compounds. ${ }^{23}$ Since we ${ }^{7,8}$ and others ${ }^{24-27}$ previously reported N-H insertion of diazoesters catalyzed by metalloporphyrins (Fe, Ru), N-H insertion with a diazo porphyrin ester was also investigated (Scheme 2). The results presented in Scheme 2 show that the iron complex is a good catalyst for the transformation of tryptophan methyl ester into the expected N-H inserted products with 69\% yield. It should be noted that only the dimerization was observed with the ruthenium complex. 


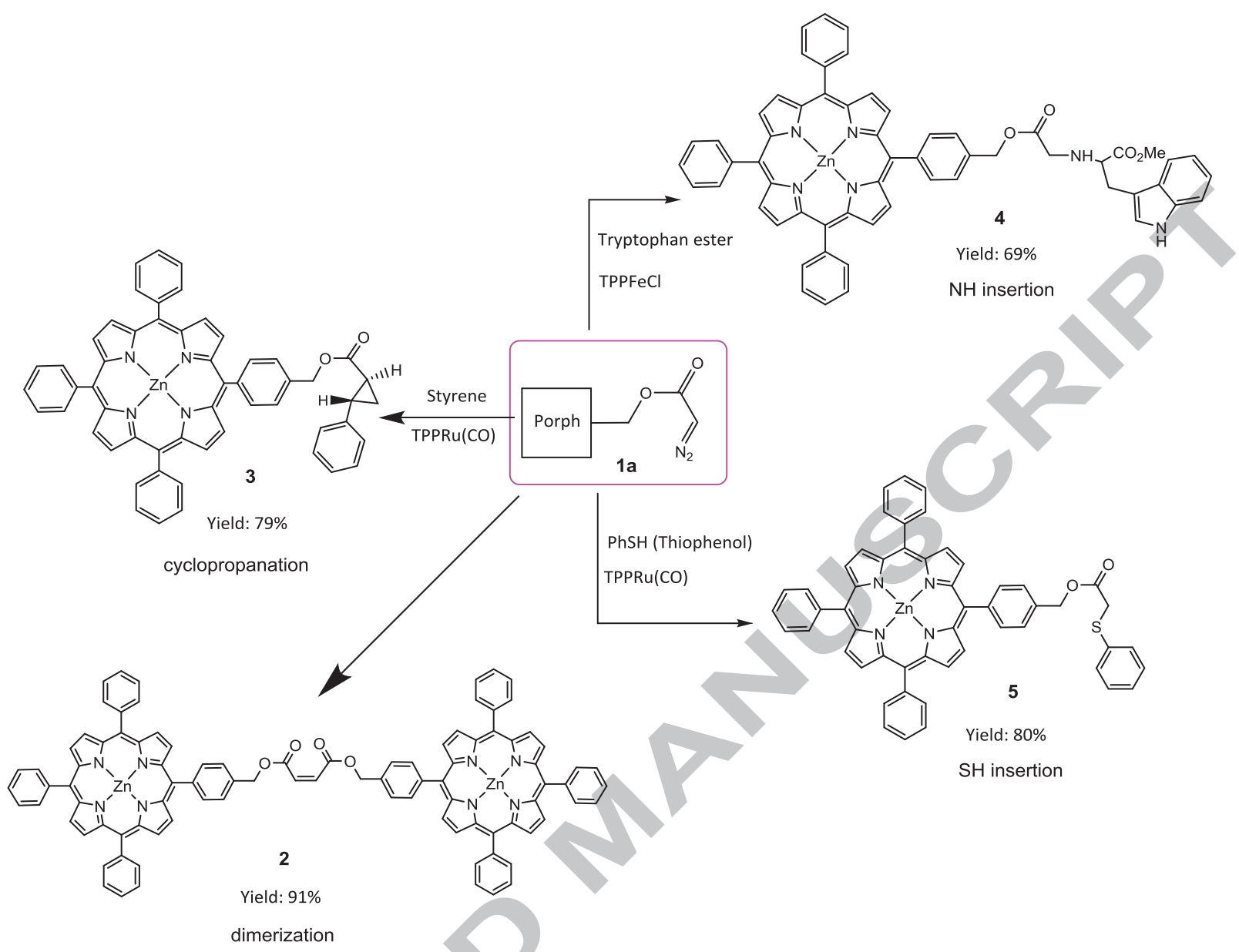

Scheme 2. Reactivity of diazoporphyrin esters.

Since peptidyl diazomethyl ketones appeared initially to be specific inactivators of cysteine proteinases, ${ }^{28}$ insertion of diazoporphyrin ester into S-H bonds, catalyzed by metalloporphyrins, was assayed (Scheme 2). Treatment of thiophenol with diazoporphyrin ester catalyzed by complex 1a gave insertion of the diazo derivative into the S-H bond with $85 \%$ yield. The mechanisms of the cyclopropanation reaction, $\mathrm{N}-\mathrm{H}$ insertion and S-H insertion, catalyzed by metalloporphyrins, have been previously discussed by us $^{8}$ and others ${ }^{25-}$ ${ }^{27}$ several times, and will not be presented herein. All the new derivatives were identified by NMR and mass spectral analysis. ${ }^{29}$

In summary, the synthesis of new zinc diazoporphyrin esters occurs with good yields offering for the first time a general access to original porphyrins. Studies on the application of the insertion reaction into $\mathrm{N}-\mathrm{H}$ and $\mathrm{S}-\mathrm{H}$ bonds for bioconjugation of these potentially fluorescent probes to proteins are in progress. 


\section{References and notes}

1. Ford, A.; Miel, H.; Ring, A.; Slattery, C. N.; Maguire, A. R.; McKervey, M. A. Chem. Rev. 2015, 115, 9981-10080.

2. Z Zhang, Z.; Wang, J. Tetrahedron 2008, 64, 6577-6605.

3. Gomes, A. T. P. C.; Neves, M. G. P. M. S.; Cavaleiro, J. A. S. J. Porphyrins Phthalocyanines 2011, 15, 835-847.

4. Cavaleiro, J. A. S.; Gerdan, V. M.; Hombrecher, H. K.; Neves, M. G. P. M. S.; Silva, A. M. S. Heterocycl. Commun. 1997, 3, 253-261.

5. Hombrecher, H. K.; Gerdan, V. M.; Cavaleiro, J. A. S.; Neves, M. G. P. M. S. Heterocycl. Commun. 1997, 3, 453-461.

6. $\quad$ Köpke, T.; Pink, M.; Zaleski, J. M. Synlett 2006, 14, 2183-2186.

7. Galardon, E.; Le Maux, P.; Simonneaux, G. J. Chem. Soc., Perkin Trans. 1 1997, 2455-2456.

8. Galardon, E.; Le Maux, P.; Simonneaux, G. Tetrahedron 2000, 56, 615-621.

9. Srour, H. F.; Le Maux, P.; Chevance, S.; Carrie, D.; Le Yondre, N.; Simonneaux, G. J. Mol. Cat. A.: Chem. 2015, 407, 194-203.

10. Nicolas, I.; Roisnel, T.; Le Maux, P.; Simonneaux, G. Tetrahedron Lett. 2009, 50, 5149-5151.

11. Simonneaux, G.; Tagliatesta, P. J. Porphyrins Phthalocyanines 2004, 8, 1166-1171.

12. Toma, T.; Shimokawa, J.; Fukuyama, T. Org. Lett. 2007, 9, 3195-3197.

13. Tamiaki, H.; Kumon, K.; Shibata, R. J. Porphyrins Phthalocyanines 2007, 11, 434-441.

14. Le Maux, P.; Nicolas, I.; Chevance, S.; Simonneaux, G. Tetrahedron 2010, 66, 4462-4468.

15. Collman, J. P.; Rose, E.; Venburg, G. D. J. Chem. Soc., Chem. Commun. 1993, 934-935.

16. Le Maux, P.; Roisnel, T.; Nicolas, I.; Simonneaux, G. Organometallics 2008, 27, 3037-3042.

17. Woo, L. K.; Smith, D. A. Organometallics 1992, 11, 2344-2346.

18. Graban, E.; Lemke, F. R. Organometallics 2002, 21, 3823-3826.

19. Oshima, T.; Nagai, T. Tetrahedron Lett. 1980, 21, 1251-1254.

20. Shankar, B. K. R.; Shechter, H. Tetrahedron Lett. 1982, 23, 2277-2280.

21. Hodgson, D. M.; Angrish, D. Chem. Eur. J. 2007, 13, 3470-3479.

22. Galardon, E.; Le Maux, P.; Simonneaux, G. J. Chem. Soc., Chem. Commun. 1997, 927-928.

23. Zaragoza, F. Tetrahedron 1997, 53, 3425-3439.

24. Aviv, I.; Gross, Z. Chem. Commun. 2006, 4477-4479.

25. Baumann, L. K.; Mbuvi, H. M.; Du, G.; Woo, L. K. Organometallics 2007, 26, 3995-4002.

26. Aviv, I.; Gross, Z. Chem. Eur. J. 2008, 14, 3995-4005.

27. Ho, C. M.; Zhang, J. L.; Zhou, C. Y.; Chan, O. Y.; Yan, J. J.; Zhang, F. Y.; Huang, J. S.; Che, C. M. J. Am. Chem. Soc. 2010, 132, 1886-1894.

28. Shaw, E. Methods Enzymol. 1994, 244, 649-656. 
29. All new compounds reported here gave spectral data consistent with the assigned structures. Reaction conditions and selected data: For 1. To a distilled $\mathrm{CH}_{2} \mathrm{Cl}_{2}$ solution (5 mL) of Zinc 5-[4-(hydroxymethyl)phenyl]-10,15,20-triphenylporphyrin ${ }^{13}$ (100 mg, $0.14 \mathrm{mmol}), 3$ eq of DBU $(0.42 \mathrm{mmol})$ were first added under argon at $0^{\circ} \mathrm{C}$ and then 1.5 eq of bromo acetyl bromide $(0.21 \mathrm{mmol})$. The reaction mixture was stirred for 10 min at room temperature. After cooling the solution again to $0^{\circ} \mathrm{C}$, a THF solution of ditosylhydrazine (2 eq) and DBU (5 eq) was added and the mixture was stirred for 30 min at room temperature. The solution was then evaporated, dissolved in $\mathrm{CH}_{2} \mathrm{Cl}_{2}$ and purified through a silica gel column $\left(\mathrm{CH}_{2} \mathrm{Cl}_{2}\right)$. Yield $=72 \%$. ${ }^{1} \mathrm{H}$ NMR $\left(\mathrm{CD}_{2} \mathrm{Cl}_{2}, \mathrm{ppm}\right.$, $400 \mathrm{MHz}$ ): $\delta 8.99$ (m, 8H, $\beta$ pyrrole), 8.33-8.20 (m, 8H, phe), 7.90-7.72 (m, 11H,


MHz): $\delta$ 166.8(CO), 150.1, 142.5, 135.5, 134.5, 132.0, 127.5, 126.5, 126.2, 121.1, $66.4\left(\mathrm{CH}_{2} \mathrm{O}\right), 30.6\left(\underline{\mathrm{CHN}}_{2}\right)$. HRMS (ESI): calcd for $\mathrm{C}_{47} \mathrm{H}_{30} \mathrm{~N}_{6} \mathrm{O}_{2} \mathrm{Zn} \quad(\mathrm{M}+\mathrm{H})^{+}$: 774.17162, found: 774.1719. UV-vis $\left(\mathrm{CH}_{2} \mathrm{Cl}_{2}\right): \lambda_{\max }, \mathrm{nm}\left(\varepsilon \mathrm{cm}^{-1} \mathrm{mM}^{-1}\right): 421$ (365.90), 549 (14.39), 592 (3.47). For 2. To a distilled $\mathrm{CH}_{2} \mathrm{Cl}_{2}$ solution (1 mL) containing 0.9 $\mathrm{mg}$ of TPPRuCO, $8.6 \mathrm{mg}(0.01 \mathrm{mmol})$ of 1 dissolved in $2 \mathrm{ml}$ of $\mathrm{CH}_{2} \mathrm{Cl}_{2}$ was added under argon. The mixture was stirred for $24 \mathrm{~h}$ at room temperature. The solution was then evaporated and purified by chromatography on silica gel column $\left(\mathrm{CH}_{2} \mathrm{Cl}_{2}\right)$. Yield $=91 \% .{ }^{1} \mathrm{H}$ NMR ( $\left.\mathrm{CD}_{2} \mathrm{Cl}_{2}, \mathrm{ppm}, 400 \mathrm{MHz}\right): \delta 9-8.85$ (m, 16H, $\beta$ pyrrole), 8.3-8.1 (m, 18H, Phe), 7.90-7.72 (m, 20H, Phe), 6.62 (s, 2H, $\mathrm{CH}_{2}$ ), 5.67 (s, 4H, $\mathrm{CH}_{2} \mathrm{O}$ ). ${ }^{13} \mathrm{C} \mathrm{NMR}$ (CD $\mathrm{Cl}_{2}$, ppm, $\left.100 \mathrm{MHz}\right): \delta 165.2$ (CO), 151.0, 143.0, 135.1, 134.9, 132.5, 130.1 $\left(\mathrm{CH}_{\text {cis }}\right), 127.5,126.4,126.2,67.2\left(\mathrm{CH}_{2} \mathrm{O}\right)$. HRMS (ESI): calcd for $\mathrm{C}_{94} \mathrm{H}_{60} \mathrm{~N}_{8} \mathrm{O}_{4} \mathrm{Zn}_{2}$ $(\mathrm{M})^{+}:$1492.33149, found: 1492.3311 . UV-vis $\left(\mathrm{CH}_{2} \mathrm{Cl}_{2}\right): \lambda_{\max }, \mathrm{nm}\left(\varepsilon \mathrm{cm}^{-1} \mathrm{mM}^{-1}\right): 421$ (485.59), 550 (20.58), 594 (5.15). For 3. To a distilled $\mathrm{CH}_{2} \mathrm{Cl}_{2}$ solution (1mL) containing $25 \mu \mathrm{l}$ of styrene and $0.9 \mathrm{mg}$ of TPPRuCO under argon, $15.8 \mathrm{mg}$ of $\mathbf{1}$ dissolved in $2 \mathrm{ml}$ of $\mathrm{CH}_{2} \mathrm{Cl}_{2}$ was added progressively $(1 \mathrm{ml} / \mathrm{h})$. The mixture was stirred overnight. The solution was then evaporated and purified by chromatography on silica gel column. Yield $=79 \%$. ${ }^{1} \mathrm{H}$ NMR $\left(\mathrm{CD}_{2} \mathrm{Cl}_{2}, \mathrm{ppm}, 400 \mathrm{MHz}\right): \delta 8.99(\mathrm{~m}, 8 \mathrm{H}$, pyrrole), 8.31-8.21 (m, 8H, phe), 7.90-7.72 (m, 11H, phe), 7.38-7.30 (m, 2H, phe), 7.28-7.23 (m, 1H, phe), 7.22-7.16 (m, 2H, phe), 5.53 (s, 2H, $\mathrm{CH}_{2}$ ), 2.64-2.57 (m, 1H, cyclo), 2.12-2.05 (m, cyclo), 1.72-1.64 (m,1H, cyclo), 1.49-1.41 (m,1H, cyclo). ${ }^{13} \mathrm{C}$ NMR ( $\mathrm{CD}_{2} \mathrm{Cl}_{2}$, ppm, $\left.100 \mathrm{MHz}\right): \delta 173.6$ (CO), 150.1, 142.8, 142.7, 140.2, 135.6, 134.5, 132.0, 128.4, 127.5, 126.5, 126.2, 121.6, 121.2, 66.4, 26.2, 24.1, 17.1. HRMS 
(ESI): calcd for $\mathrm{C}_{55} \mathrm{H}_{38} \mathrm{~N}_{4} \mathrm{O}_{2} \mathrm{Zn}(\mathrm{M}+\mathrm{H})^{+}$: 850.22807, found: 850.2276. UV-vis $\left(\mathrm{CH}_{2} \mathrm{Cl}_{2}\right): \lambda_{\max }, \mathrm{nm}\left(\varepsilon \mathrm{cm}^{-1} \mathrm{mM}^{-1}\right): 421$ (357.50), 550 (10.43), 592 (1.08). For 4. To a distilled $\mathrm{CH}_{2} \mathrm{Cl}_{2}$ solution (1mL) containing $2.3 \mu \mathrm{l}$ of triethylamine (1.5 eq), $0.6 \mathrm{mg}$ of TPPFeCl and $2.8 \mathrm{mg}$ (0.01 mmol) of L- tryptophan methyl ester hydrochloride, 8.6 $\mathrm{mg}$ (0.01 mmol) of 1 dissolved in $2 \mathrm{ml}$ of $\mathrm{CH}_{2} \mathrm{Cl}_{2}$ was added under argon. The mixture was stirred for $15 \mathrm{~min}$. The solution was then evaporated and purified by chromatography on silica gel column $\left(\mathrm{CH}_{2} \mathrm{Cl}_{2} / \mathrm{CH}_{3} \mathrm{OH}\right.$ : 98/2). Yield $=69 \%$. ${ }^{1} \mathrm{H} \mathrm{NMR}$ ( $\mathrm{CD}_{2} \mathrm{Cl}_{2}$, ppm, $400 \mathrm{MHz}$ ): $\delta 8.97$ (m, 8H, $\beta$ pyrrole), 8.36-8.24 (m, 8H, Phe), 7.93 (s, 1H, NH), 7.81-7.60 (m, 11H, Phe), 7.27 (d, 1H, tryp), 7.11 (t, 1H, tryp), 6.94 (t, 1H, tryp), 6.84 (d, 1H, tryp), 5.87 (s, 1H, tryp), 4.93 (s, 2H, $\mathrm{CH}_{2} \mathrm{O}$ ), 3.05 (s, 3H, $\mathrm{CH}_{3}$ ), 1.4 and $0.5\left(\mathrm{~m}, 2 \mathrm{H}, \mathrm{CH}_{2}\right), 0.4\left(\mathrm{~m}, 2 \mathrm{H}, \mathrm{CH}_{2} \mathrm{~N}\right), 0.39\left(\mathrm{~m}, 1 \mathrm{H}, \mathrm{CH}^{*}\right) .{ }^{13} \mathrm{C} \mathrm{NMR}\left(\mathrm{CD}_{2} \mathrm{Cl}_{2}\right.$, ppm, $100 \mathrm{MHz}$ ): $\delta 169.5$ (CO), 168.0 (CO), 149.1, 141.5, 135.0, 134.5, 132.0, 127.0, 126.5, 126.0, 121.1, 110.0, $67\left(\mathrm{CH}_{2} \mathrm{O}\right), 57.5\left(\mathrm{C}^{*}\right), 43.0\left(\mathrm{CH}_{2} \mathrm{~N}\right), 52.0\left(\mathrm{CH}_{3}\right), 24.8$ $\left(\mathrm{CH}_{2}\right)$. HRMS (ESI): calcd for $\mathrm{C}_{59} \mathrm{H}_{45} \mathrm{~N}_{6} \mathrm{O}_{4} \mathrm{Zn} \quad(\mathrm{M}+\mathrm{H})^{+}:$965.27882, found: 965.2790. UV-vis $\left(\mathrm{CH}_{2} \mathrm{Cl}_{2}\right): \lambda_{\max }, \mathrm{nm}\left(\varepsilon \mathrm{cm}^{-1} \mathrm{mM}^{-1}\right): 421$ (272.90), 551 (11.47), 592 (1.90). For 5. To a distilled toluene solution (1mL) o2.86 mg $(0.026 \mathrm{mmol})$ of thiophenol and $0.6 \mathrm{mg}$ of TPPRuCO under argon, $2.9 \mathrm{mg}$ (0.02 mmol) of 1 dissolved in $0.5 \mathrm{ml}$ of toluene was added over a period of $30 \mathrm{~min}$. The reaction was then stirred for 4 hours at room temperature. The mixture was concentrated by vacuum evaporation and purified by silica gel chromatography. Yield $=85 \%)$. ${ }^{1} \mathrm{H}$ NMR ( $\mathrm{CD}_{2} \mathrm{Cl}_{2}$, ppm, $400 \mathrm{MHz}$ ): $\delta \delta$ 9.10-8.90 (m, 8H, pyrrole), 8.35-8.15 (m, 8H, phe), 7.95-7.75 (m, 9H, phe), 7.75-7.68 (m, 2H, phe), 7.56-7.50 (m, 2H, phe), 7.43-7.35 (m, 1H, phe), 7.33-7.25 (m, 2H, phe) 5.52 (s, 2H, $\mathrm{CH}_{2} \mathrm{O}$ ), 3.88 (s, 2H, $\mathrm{CH}_{2} \mathrm{~S}$ ). ${ }^{13} \mathrm{C} \mathrm{NMR}^{-1}$ ( $\mathrm{CD}_{2} \mathrm{Cl}_{2}$, ppm, $100 \mathrm{MHz}$ ): $\delta 169.7$ (CO), 150.3, 142.9, 127.0, 134.5, 132.0, 130, 129.1, 127.5, 127.1, 126.6, 126.3, 121.2, 120.4, $67.36\left(\mathrm{CH}_{2} \mathrm{O}\right), 36.6\left(\mathrm{CH}_{2} \mathrm{~S}\right) . \mathrm{HRMS}(\mathrm{ESI})$ : calcd for $\mathrm{C}_{53} \mathrm{H}_{36} \mathrm{~N}_{4} \mathrm{O}_{2} \mathrm{SZn}(\mathrm{M}+\mathrm{H})^{+}$: 856.18449, found: 856.1841. UV-vis $\left(\mathrm{CH}_{2} \mathrm{Cl}_{2}\right)$ : $\lambda_{\max }, \mathrm{nm}\left(\varepsilon \mathrm{cm}^{-1} \mathrm{mM}^{-1}\right): 422$ (251.76), 550 (8.93), 592 (1.32). 
Highlights :

First synthesis of Zinc porphyrin diazoacetates

$\mathrm{NH}$ of tryptophan ester by porphyrin diazo esters

Cyclopropanation of styrene by porphyrin diazo esters

Preparation of porphyrin dimers by diazo coupling reaction

SH insertion of thiophenol by porphyrin diazo esters 